\title{
InfoNorth
}

\section{Illegal, Unreported and Unregulated Fishing in the Circumpolar Arctic}

by Magdalena A.K. Muir

\section{INTRODUCTION}

$\mathrm{C}$ LIMATE CHANGE HAS INCREASED both marine access to much of the circumpolar Arctic and the migration of fish stocks into northern waters. As fish stocks become depleted in southern jurisdictions, Arctic fish stocks could become more attractive for illegal, unreported, and unregulated (IUU) fishing. This situation has many parallels with the experiences of IUU fishing in the Southern Ocean around the Antarctic. However, unlike those in Antarctica, fish and marine mammal stocks in the circumpolar Arctic are subject to indigenous and local subsistence harvesting, which has priority over commercial harvesting. Arctic fish stocks are also characterized by lower growth rates, which increase their vulnerability to the impact of IUU fishing.

In the Canadian Arctic, because of slow fish growth, limited seasonal fishing opportunities, and the high cost of shipping, extensive ecosystem and economic changes would be required to make commercial fisheries feasible. Fisheries have been very close to shore throughout the Canadian Arctic. Though attempts have been made to harvest Arctic char (Salvelinus alpinus) commercially, this species has been harvested primarily for subsistence and recreation. Arctic cisco (Coregonus autumnalis) or Pacific herring (Clupea palasii) are potential commercial fishery targets in the Canadian Beaufort Sea, but these harvests would be subject to beluga whale feeding requirements.

In this essay, I explore several northern fisheries to examine various IUU fishing scenarios for the Arctic: commercial fishing in the Canadian and U.S. Beaufort Sea, the offshore halibut fishery adjacent to the Nunavut Territory of Canada, and the Irminger Sea redfish fishery in the Reykjanes Ridge of the North Atlantic. I then consider current regulatory regimes for IUU fisheries in Antarctica and Europe, which provide potential models for Arctic fisheries.

\section{International Framework}

Exclusive Economic Zones established under the United Nations Convention on the Law of the Sea (UNCLOS) indicate the outer boundaries of national fishing rights and management regimes (United Nations, 1982). The Agreement on fish stocks (United Nations, 1995), an implementing agreement under UNCLOS that has been in force since 2001, applies to both Exclusive Economic Zones and international waters. It is designed to promote the long-term conservation and sustainable use of straddling fish species (whose geographical range includes Exclusive Economic Zones and international waters) and highly migratory fish species in international waters.

Under the Agreement on fish stocks, regional fishery management organizations and arrangements are the preferred mechanisms for fishery management. The Agreement imposes obligations on signatories to cooperate through such regional bodies and arrangements, and access to fish stocks is limited to cooperating states. States can become members of the regional organizations or participate in regional arrangements. Members and participants can enforce their rules against external parties or non-signatories to these agreements, using measures that would otherwise be viewed as trade-related sanctions in violation of international law (i.e., World Trade Organization, 1994).

Regional fishery management organizations established under conventions that affect Arctic fisheries include the Northwest Atlantic Fisheries Organization (NAFO) and its Fisheries Commission, the North Atlantic Salmon Conservation Organization, the North East Atlantic Fisheries Commission, the North Pacific Anadromous Fish Commission, and the Norway-Russian Federation Fisheries Commission (Molenaar and Corell, 2009).

Boundary disputes may complicate the characterization of what constitutes an illegal fishery. Different countries may impose different regulatory regimes on the same fish stocks. For example, Canada has disputed marine boundaries with the United States and Greenland, as Norway does with Russia. Such disputes create ambiguity about who has legal access to disputed areas and the right to use and manage both nonrenewable and renewable resources, including fish and marine mammals, in those areas. Norway and Russia recently ended a 40 -year dispute by dividing a disputed area in the Barents Sea evenly, thus also resolving jurisdictional issues over fisheries. That agreement is dated 27 April 2010, but the technical terms and implementation are still to be determined (Anon, 2010).

\section{Canadian and U.S. Beaufort Sea}

The United States and Canada have ongoing disputes over the ownership and control of the sea floor, surface, and water column in the Beaufort Sea (see Ingenfeld, 2010: Fig. 1). Canada asserts that the Beaufort Sea boundary is a 


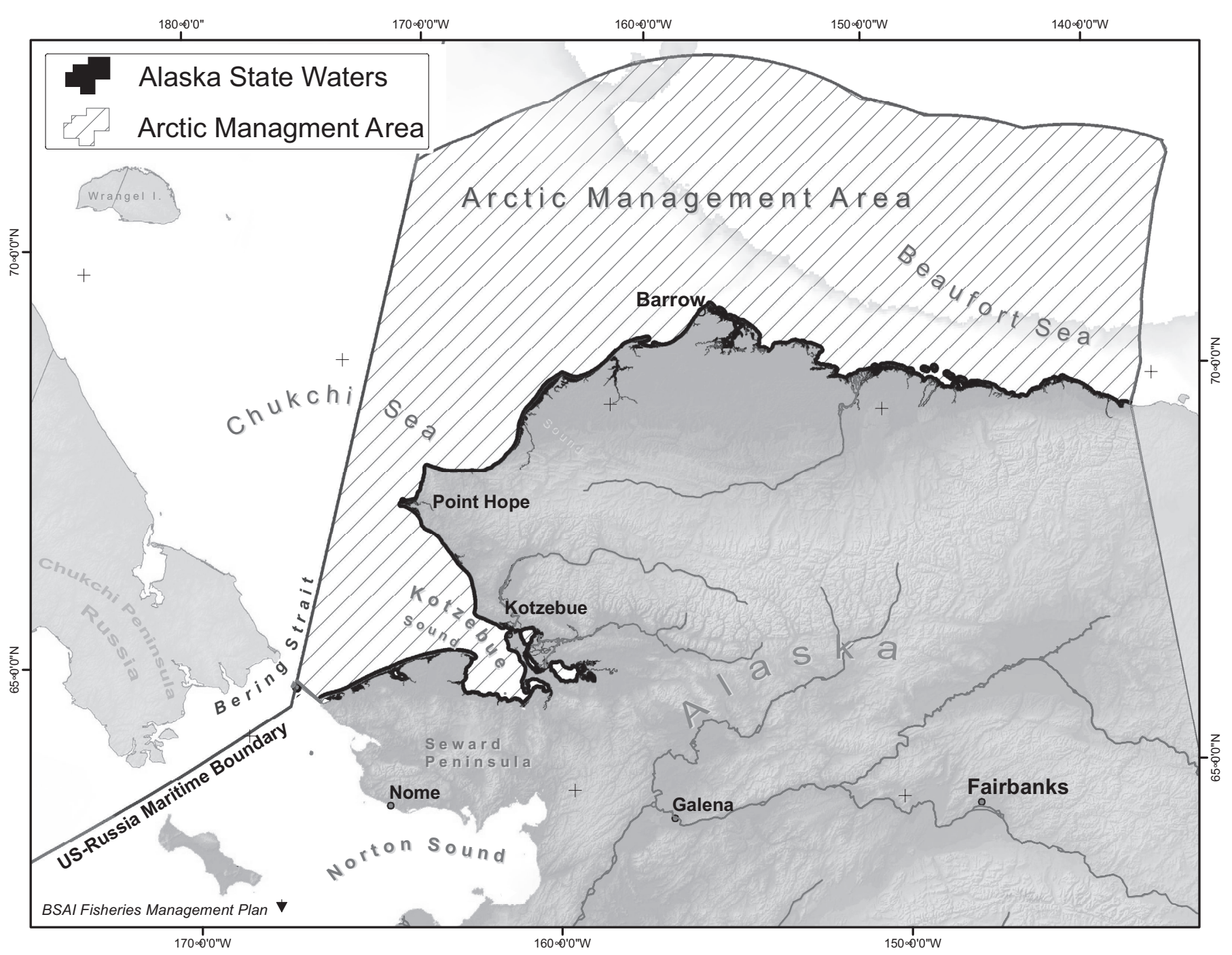

FIG. 1. The area of the U.S. Arctic Fishery Management Plan (NOAA, 2010).

linear extension of the boundaries on land, while the United States asserts that the boundary begins at a $90^{\circ}$ angle to the shoreline. This boundary dispute has historically focused on hydrocarbons, but the Arctic Fishery Management Plan (Fig. 1) enacted by the United States in 2009 may precipitate a future focus on commercial fishing rights. Given the overlap of the areas claimed by the two countries, parties legally authorized to fish in the Canadian Beaufort Sea would be fishing illegally under U.S. law.

The recent U.S. Arctic Fishery Management Plan (NPFMC, 2009) prohibits the expansion of commercial fishing in Arctic federal waters until researchers have gathered enough information on fish stocks and the Arctic marine environment to implement sustainable fisheries. Arctic cod (Boreogadus saida), saffron cod (Eleginus gracialis), and snow crab (Chionoecetes opilio) are identified as likely initial target species for commercial fishing in the Beaufort Sea. The plan will govern future commercial fishing in federal waters for all fish and shellfish species except Pacific salmon (Oncorhynchus sp.) and Pacific halibut
(Hippoglossus stenolepis), which are subject to other controls. However, it will not affect either fisheries for salmon, whitefish, and shellfish in Arctic waters near the Alaskan shore or subsistence fishing and hunting in the Arctic.

At this time, no commercial fisheries operate in the Canadian Beaufort Sea, but there are Inuvialuit and Gwich'in subsistence fisheries and recreational fisheries. If commercial fishing opportunities arise, the Inuvialuit and Gwich'in will be involved. In May 2010, the Standing Committee on Fisheries and Oceans of the Canadian Senate recommended that the federal government, in cooperation with the Inuvialuit, develop a policy for fishing activity for the Beaufort Sea. It also recommended that Canada institute a moratorium on commercial fishing similar to the one instituted by the United States under the Arctic Fishery Management Plan (SSCFO, 2010). The United States and Canada are also currently engaged in discussions aimed at resolving outstanding boundary disputes, which could also resolve IUU fishery issues for the Beaufort Sea. 


\section{Internal IUU Fishing in Canada}

Greenlandic halibut (Reinhardtius hippoglossoides, also known as turbot) and shrimp (Pandalus borealis, northern or pink shrimp) are fished offshore of Nunavut within Davis Strait and Baffin Bay. Greenlandic halibut is found within the Northwest Atlantic Fisheries Organization's subarea 0, which includes Canadian waters adjacent to the Nunavut Territory (Fig. 2). Canada manages these waters in subarea 0 on the basis of the conservation and catch recommendations from the scientific council under the Northwest Atlantic Fisheries Convention. The Canadian management plan, which is subject to the Nunavut Land Claims Agreement of 1993, includes Inuit participation in and management of offshore fisheries (DFO, 2006-08).

Previously, there were questions about how the halibut catch should be allocated within Canada, whether the existing allocation by the federal government was illegal, and whether Nunavut halibut fisheries should have greater priority in that allocation. In the 1990s, the Minister of Fisheries and Oceans Canada allocated the total allowable catch of halibut both within and outside Nunavut. Nunavut Tunngavik Incorporated, the corporation representing the Inuit beneficiaries under the Nunavut Land Claims Agreement, protested through litigation, claiming this allocation was inconsistent with the constitutionally protected Agreement.

Article 15.3.7 of the Agreement recognizes the importance of adjacency and the economic dependence of communities in the Nunavut Settlement Area on marine resources, obliges the government to give special consideration to these factors when allocating commercial fishing licences, and stipulates that the principles of adjacency and economic dependence will be applied in such a way as to promote a fair distribution of licences between territorial residents and residents of other parts of Canada that is consistent with Canada's inter-jurisdictional obligations.

In 2002, the Independent Panel on Access Criteria appointed by the Minister of Fisheries and Oceans Canada issued a report on the criteria used for granting licences in new or emerging fisheries. Because Nunavut did not enjoy the same access to its adjacent fisheries that is granted to the Atlantic provinces, the panel concluded that every effort should be made to remedy this situation. In keeping with the spirit of the Nunavut Land Claims Agreement, and the fair and consistent application of the adjacency principle, the panel recommended that no additional access be granted to non-Nunavut interests in adjacent waters until Nunavut had a major share of adjacent fishery resources. This recommendation was accepted by the Minister of Fisheries and Oceans Canada (DFO, 2002).

This ended an allocation for the Greenlandic halibut that was illegal under Canadian law, as all laws are invalid to the extent that they are inconsistent with a constitutionally protected land-claim agreement. Since that time, Nunavut fisheries have been receiving a larger share of the halibut quota allocation, and parties based in Nunavut are participating in commercial halibut fishing in these waters. Four

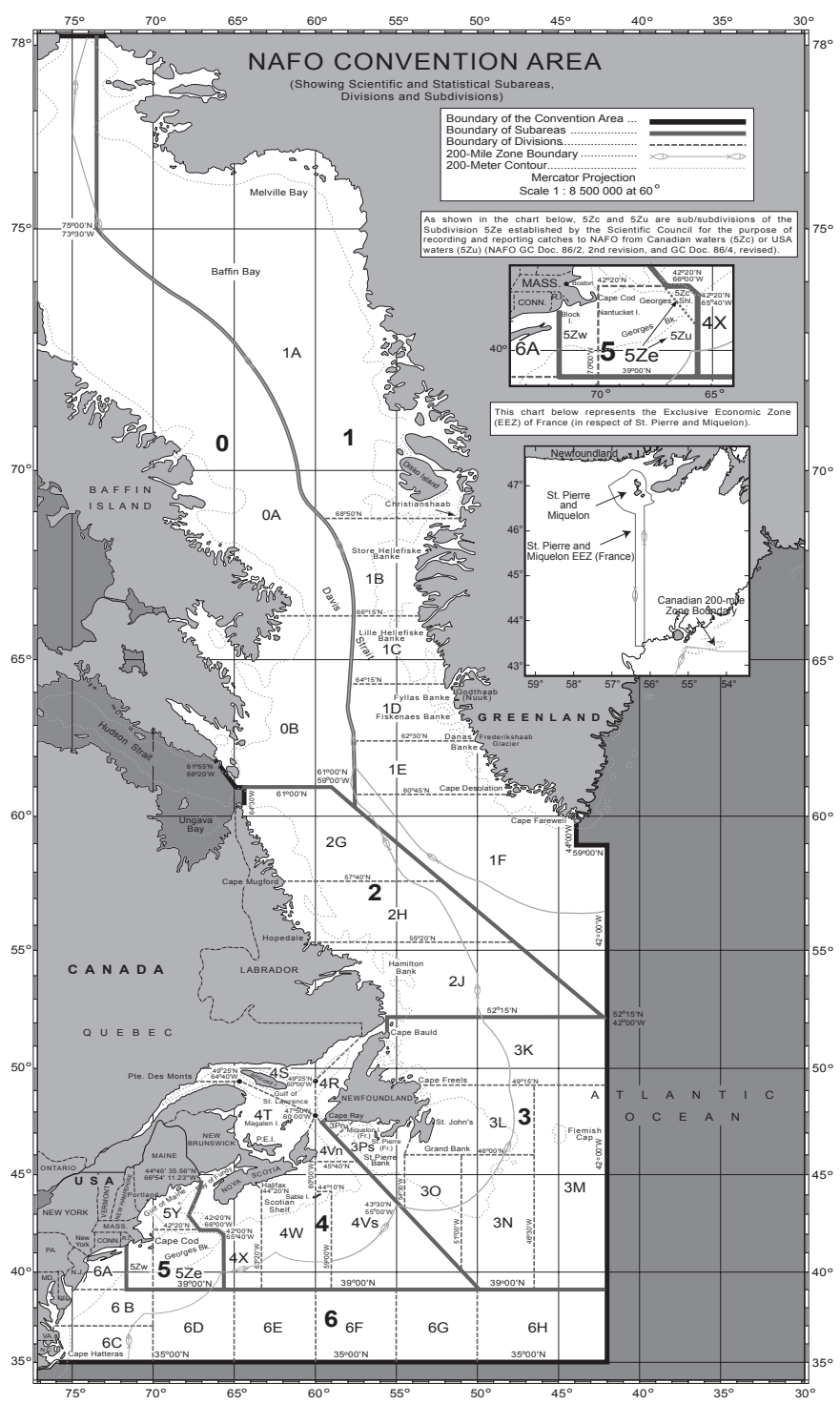

FIG. 2. Map showing the location of NAFO Convention subarea 0 . Courtesy of NAFO.

organizations with local Inuit involvement now hold $100 \%$ of Nunavut's Greenlandic halibut and shrimp quota (DFO, 2009). The territorial government has developed a policy for allocating quotas to Nunavut's existing commercial marine fisheries, and it is also conducting scientific research to determine the nature and scope of possible commercial fisheries for species such as char, clams, and sea urchins (Nunavut Department of Environment, 2010). Sound scientific research is critical to the sustainable development and management of inshore and offshore fisheries.

\section{The Irminger Sea Redfish Fishery}

The Irminger Sea redfish (Sebastes mentella) stock is found near the Reykjanes Ridge in the North Atlantic, adjacent to the Icelandic Exclusive Economic Zone (Fig. 3). Redfish is a straddling fish stock under the North East Atlantic Fisheries Commission (NEAFC) that is subject to 


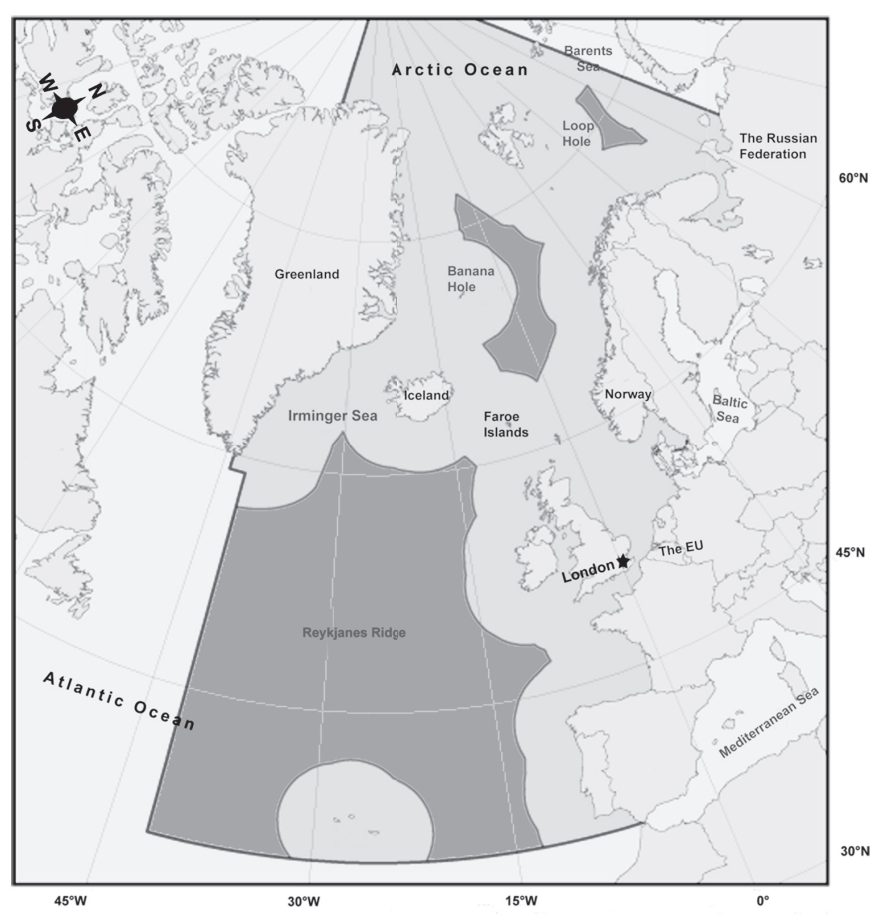

FIG. 3. Map of the NEAFC Regulatory Area, showing the Reykanes Ridge and Irminger Sea (NEAFC, 2010).

illegal fishing in the Irminger Sea by ships flying flags of convenience. These ships are registered in countries that are not members of the NEAFC Convention and do not have an allocation, and they are fishing illegally (Greenpeace, 2006).

These illegal fishing ships are being monitored through surveillance activities by Iceland and other parties, and they are not permitted to enter Icelandic ports. Information garnered through the surveillance activities is also used in regional anti-IUU co-operation under the North East Atlantic Fisheries Convention of 1959, as substantially amended by the Convention on future multilateral cooperation in North East Atlantic fisheries of 1982. Iceland also undertakes bilateral action with the ship's flag state, the state where the ship's operator is located, the state where the ship's underlying ownership is held, and the state where the company that sells the fish is registered (Hoydal, 2009).

The Irminger Sea redfish that is being harvested illegally near the Reykjanes Ridge may be transported to China and processed there and then resold in Canada. The question arises how consumers and governments can ensure that redfish imports do not contribute to IUU fishing in the Arctic. In addition to regulation under regional organizations and conventions, consumer actions could be useful. Consumer action could include uniform labeling requirements or sustainable fishery certifications.

The existing IUU fishery regime for Antarctica and the one recently enacted IUU fishery regime in Europe are now explored in order to consider whether aspects of these regimes could also be effective at addressing IUU fisheries in the circumpolar Arctic.

\section{ANTARCTICA AND EUROPEAN IUU FISHING REGIMES}

\section{CCAMLR and IUU Fisheries}

The Convention on the Conservation of Antarctic Marine Living Resources (CCAMLR) came into force in 1982 under Article IX of the Antarctica Treaty of 1959. The Convention was established because of concern that increased krill catches in the Southern Ocean could negatively affect the krill population and the birds, seals, and fish that depend on krill for food. The aim of the Convention is to conserve marine life of the Southern Ocean. Conservation measures are based on scientific advice and require enforcement to be effective. A precautionary approach has been implemented to minimize risk associated with unsustainable practices in conditions of uncertainty, and it is complemented by an ecosystem approach (CCAMLR, 2008).

IUU fishing is a significant issue in the Convention area and adjacent waters. CCAMLR estimates of IUU fishing exceed allowable catches under the Convention. These illegal catches have been taken in national waters within the Convention Area or in a manner different from or contrary to management measures aimed at controlling and monitoring unregulated and unreported catches.

CCAMLR introduced catch documentation schemes in 2000 to monitor landings of and global trade in the Patagonia toothfish or Chilean sea bass (Dissostichus eleginoides) in order to assess and combat IUU fishing for this species. This documentation enables the Commission established under the Convention to identify the origin of fish entering the markets of all parties and helps to determine whether the fish were caught in a manner consistent with conservation measures.

Other CCAMLR conservation measures include strict vessel licensing requirements, at-sea and in-port vessel inspections, and the requirement for the continuous monitoring of vessel positions in the Convention area using automated satellite-linked monitoring systems. For some fisheries, flag states are required to transmit real-time vessel position information to a central database. CCAMLR also conducts annual reviews of information on IUU fishing activities and has established a list of IUU vessels. Together, these initiatives have contributed to a significant decline in IUU fishing since 2003 (CCAMLR, 2010).

\section{European Union IUU Regulations}

The definition of IUU fishing in the European Union (EU) IUU Regulations of 2008 to 2010 was based on an earlier FAO International Plan of Action of 2001 (FAO, 2001). The new EU regulations are intended to prevent, deter, and eliminate IUU fishing and focus on both EU fishers and EU consumers. The IUU Regulations apply to 1) fishing occurring in European Community waters; 2) fishing in Exclusive Economic Zones and international waters that are subject to a regional fishery management organization, if 
conducted by ships without a flag state or from a flag state that is not party to the regional agreement or by any ship that contravenes the rules of the organizations; and 3) fishing in international waters that occurs in breach of flag state responsibilities under international law for the conservation of fisheries (European Commission, 2010).

Through the IUU Regulations that came into effect on 1 January 2010, the European Union (2008, 2009, 2010a, b) is preventing illegal operators from selling fish in Europe. The IUU Regulations prevent fish caught from illicit activities from entering the European market because all marine fishery products must be certified and their origin must be traceable. A comprehensive catch certification scheme makes sure that fish caught, landed, brought to market, and sold in Europe can be tracked at any stage of the process. Now only marine fishery products validated as legal by the relevant flag state or exporting state can be imported to or exported from the European Union (European Commission, 2009).

A European black list has been drawn up covering both IUU ships and states that permit illegal fishing activities. European operators who fish illegally anywhere in the world, under any flag, face substantial penalties proportionate to the economic value of their catch, which would deprive them of any profit. Modern technologies are used to track fish products through every step of the market chain. The same offence will be subject to the same sanction wherever it takes place and whatever the fisherman's nationality or flag. There is also a point system for serious infringements, which can ultimately result in wrongdoers' losing their licence to fish (European Union, 2010a, b).

\section{SUMMARY}

Potential illegal, unreported, and unregulated fisheries in the circumpolar Arctic could take several forms. As discussed earlier, these problematic fisheries might arise through international boundary disputes, internal conflicts, or inappropriate fishing in national and international waters. The IUU fishing regimes for Antarctica and Europe provide models for addressing such fisheries in the circumpolar Arctic. The Antarctic model under CCAMLR, which is the most longstanding approach to IUU fisheries, reflects the overlapping international claims in the Southern Ocean and the importance of that ocean for fishing. The EU approach is similar to CCAMLR, but also includes restrictions on consumption of IUU fish within European and national markets.

In the Arctic, there are eight circumpolar nations with existing Exclusive Economic Zones. The future continental shelf extensions under UNCLOS, if approved, will extend to most of the Arctic Ocean, and provide significant resource use and management rights to these nations for the seabed and overlying waters. These Arctic nations, which include Canada and the United States, the Scandinavian countries, and Russia, are also major importers and consumers of fish.
Therefore it might be useful to include a consideration of the consumption of IUU fish in their national approaches.

Both the Antarctic and EU models for IUU fisheries can provide good examples for circum-Arctic approaches. Combined with efforts of regional fishing organizations and conventions and consumer awareness of sustainable fishery certifications, these Arctic approaches could help to minimize the risks of future IUU fisheries. As fish stocks move northward, and commercial fisheries develop, these national and regional approaches could also be formalized in a broader regional agreement for fisheries in the Arctic Ocean.

\section{ACKNOWLEDGEMENTS}

The author would like to thank Steve Lewis, for the map of the Arctic Fishery Management Plan area; Alex Pacey, for the map of the Northwest Atlantic Fisheries Organization Convention Area; and Rachel Lewley, for the map of the North East Atlantic Fisheries Commission regulatory area. The author gratefully acknowledges the financial support of Fisheries and Oceans Canada, which allowed her to present aspects of this essay at the 2010 conference of the Canadian Ocean Management Research Network.

\section{REFERENCES}

Anon. 2010. Russia-Norway reach agreement on demarcation of maritime borders. RIA Novosti, April 27. http://en.rian.ru/ russia/20100427/158767092.html.

CCAMLR (Convention on the Conservation of Antarctic Marine Living Resources). 2008. Basic documents. http://www.ccamlr. org/pu/e/e_pubs/bd/toc.htm.

_ 2010. Illegal, unregulated and unreported (IUU) fishing. www.ccamlr.org/pu/E/sc/fish-monit/iuu-intro.htm.

DFO (Department of Fisheries and Oceans Canada). 2002. Response to the Report of the Independent Panel on Access Criteria for the Atlantic Coast Commercial Fishery. November 8, 2002. http://www.dfo-mpo.gc.ca/afpr-rppa/IPAC_Pages/ IPAC_Response_e.htm.

2006-08. Fishery management plan, Greenland halibut, NAFO Subarea O, 2006-2008. Winnipeg, Manitoba: Fisheries and Oceans Canada.

2009. Government of Canada response to the report of the Standing Senate Committee on Fisheries and Oceans: Nunavut marine fisheries: Quotas and harbours. http://www.dfo-mpo. gc.ca/reports-rapports/200911b-eng.htm.

European Commission. 2009. Handbook on the practical application of Council Regulation (EC) No. 1005/2008 of 29 September 2008 establishing a Community system to prevent, deter and eliminate illegal, unreported and unregulated fishing (the IUU Regulation). Directorate-General for Maritime Affairs and Fisheries Policy Development and Co-ordination: Fisheries control policy. http://ec.europa.eu/fisheries.iuu.

. 2010. Illegal fishing (IUU). http://ec.europa.eu/fisheries/ cfp/illegal_fishing/index_en.htm. 
European Union. 2008. Council Regulation (EC) No 1005/2008 of 29 September 2008 establishing a Community system to prevent, deter and eliminate illegal, unreported and unregulated fishing. eur-lex.europa.eu.

. 2009. Commission Regulation (EC) No 1010/2009 of 22 October 2009 laying down detailed rules for the implementation of Council Regulation (EC) No 1005/2008 establishing a Community system to prevent, deter and eliminate illegal, unreported and unregulated fishing. eur-lex.europa.eu.

- 2010a. Commission Regulation (EC) No. 86/2010 of 29 January 2010, amending Annex I to Council Regulation (EC) No $1005 / 2008$ as regards the definition of fishery products and amending Commission Regulation (EC) No 1010/2009 as regards exchange of information on inspections of third country vessels and administrative arrangements on catch certificates. eur-lex.europa.eu.

- 2010b. Commission Regulation (EC) No 468/2010 of 28 May 2010 establishing the EU list of vessels engaged in illegal, unreported and unregulated fishing. eur-lex.europa.eu.

FAO (Food and Agriculture Organization of the United Nations). 2001. International plan of action to prevent, deter and eliminate illegal, unreported and unregulated fishing. http://www.fao. org/docrep/003/y1224e/y1224e00.HTM.

Greenpeace. 2006. Case study on IUU fishing No. 3: Caught redhanded: Daylight robbery on the high seas (May 12, 2006). Amsterdam, Netherlands: Greenpeace International. www. greenpeace.org.

Hoydal, K. 2009. Actions by the North East Atlantic Fisheries Commission against illegal, unreported and unregulated fishing vessels. Symposium on the Conservation of Fish Stocks and Illegal, Unreported and Unregulated Fishing, 26 September 2009, Hamburg, Germany.

Ingenfeld, E. 2010. "Just in case" policy in the Arctic. Arctic (InfoNorth) 63:257-259.
Molenaar, E.J., and Corell, R. 2009. Background Paper: Arctic fisheries (February 9, 2009). Arctic Transform. www.arctictransform.org/docs.html.

NEAFC (North East Atlantic Fisheries Commission). 2010. Map of the NEAFC Regulatory Area. http://www.neafc.org/page/27.

NOAA Fisheries. 2010. Map of Arctic FMP area. http://www.fakr. noaa.gov/images/arctic_fmp_area.jpg.

NPFMC (North Pacific Fishery Management Council). 2009. Fishery management plan for fish resources of the Arctic Management Area. Anchorage, Alaska: NPFMC.

Nunavut Department of Environment. 2010. The Nunavut fishing industry: Background and approach to sustainable resource development. http://www.frcc.ca/cod/briefs/Nunavut_Fishing Industry_brief_2010-045-00023.pdf.

SSCFO (Senate Standing Committee on Fisheries and Oceans). 2010. The management of fisheries and oceans in Canada's Western Arctic. http://www.parl.gc.ca/common/Committee SenRep.asp?Language $=$ E $\&$ Parl $=40 \& S e s=3 \&$ comm_id $=7$.

United Nations. 1982. United Nations Convention on the Law of the Sea (UNCLOS) of 10 December 1982. http://www.un.org/ Depts/los/convention_agreements/texts/unclos/unclos_e.pdf.

. 1995. The United Nations Agreement for the implementation of the provisions of the United Nations Convention on the Law of the Sea of 10 December 1982 relating to the conservation and management of straddling fish stocks and highly migratory fish stocks. http://www.un.org/Depts/los/ convention_agreements/convention_overview_fish_stocks. htm.

World Trade Organization. 1994. Final Act of the 1986-1994 Uruguay round of trade agreements. http://www.wto.org/ english/docs_e/legal_e/final_e.htm.

Magdalena Muir is a research associate of the Arctic Institute of North America, focusing on Arctic environment and natural resource issues and comparative studies with Antarctica, Europe, and other regions of the world. 